\title{
Association of variable number of tandem repeats polymorphism in the IL-4 gene with end-stage renal disease in Malaysian patients
}

\author{
R. Vasudevan, M.N. Norhasniza and I. Patimah \\ Genetic Research Group, Molecular Biology and Bioinformatics Unit, \\ Department of Biomedical Science, Faculty of Medicine and Health Sciences, \\ Universiti Putra Malaysia, Selangor, Malaysia \\ Corresponding author: P. Ismail \\ E-mail: patimah@putra.upm.edu.my
}

Genet. Mol. Res. 10 (2): 943-947 (2011)

Received September 15, 2010

Accepted November 29, 2010

Published May 24, 2011

DOI 10.4238/vol10-2gmr1066

\begin{abstract}
Variable number of tandem repeats (VNTR) polymorphism in the interleukin 4 (IL-4) gene has been associated with endstage renal disease (ESRD) subjects in many different populations, although with conflicting results. We determined the $70 \mathrm{bp}$ of VNTR polymorphism at intron 3 of the IL-4 gene in Malaysian ESRD subjects. Buccal cells were collected from 160 case and 160 control subjects; genomic DNA was amplified using PCR, followed by agarose gel electrophoresis. There were significant differences in genotypes and alleles of the IL-4 gene. We conclude that VNTR polymorphism of the IL-4 gene is a risk factor for the development of ESRD among Malaysians.
\end{abstract}

Key words: Genetic polymorphism; VNTR; ESRD; Interleukin 


\section{INTRODUCTION}

End-stage renal disease (ESRD) is an advanced form of chronic renal failure, where renal functions decline to $10 \%$ of normal prior to the initiation of dialysis or transplantation. The last ten years have witnessed an increase in the number of patients entering renal replacement therapy due to ESRD (Wu et al., 2003). In Malaysia, the prevalence of dialysis patients increased from 5542 in 1999 to 17,015 in 2007 and almost 19,000 in 2008 (16th Report of the Malaysian Dialysis \& Transplant Registry, 2008). ESRD has a heterogeneous etiology that results from both genetic and environmental factors. Inflammation is an important pathophysiological factor in primary renal disease and leads to the development of ESRD (Yao et al., 2004). Both dialysis-related and dialysis-unrelated factors may be related to chronic inflammation in ESRD patients (Tripathi et al., 2006). The genetic variability found in the number of interleukin genes affecting the pathogenesis of ESRD contributes in a variable manner. Variations occurring in the DNA sequences are polymorphisms. Single nucleotide polymorphisms and variable number of tandem repeats (VNTR) are the common polymorphisms found in the human genome and are considered to be the cause of various disorders. Various association studies have been conducted to identify early risk for diseases and can be applied to predict the response of specific drug treatment (Kirchheiner et al., 2006). In that way, a number of polymorphisms have been observed in interleukin genes, and several studies have shown that genetic polymorphisms play a role in the development of ESRD (Mittal and Manchanda, 2007; Tripathi et al., 2008). Interleukin-4 (IL-4) is a potent anti-inflammatory, and its gene is located on the long arm of chromosome 5 (q23-31), together with other cytokine genes. The VNTR polymorphism located in the third intron consists of three 70-bp repeats, with two repeats and four repeats of rare alleles, which are the candidate genes for this disease (Kirchheiner et al., 2006; Mittal and Manchanda, 2007; Konwar and Bid, 2008). Many studies have reported that gene polymorphism of IL-4 is associated with ESRD (Freedman et al., 1997; Nordfors et al., 2005; Wetmore et al., 2005).

Association studies of VNTR polymorphism of the IL-4 gene were carried out in many studies in various populations with conflicting results (Mittal and Manchanda, 2007; Konwar and Bid, 2008). There are many differences between Malaysians and populations of other countries, in terms of genetic background, lifestyle, socio-demographic factors, and diet. Identifying the susceptibility genes will help us in understanding the pathophysiology of the disease. This study was conducted to determine the 70-bp VNTR polymorphism of intron-3 of the IL-4 gene in Malaysian ESRD subjects. In addition, the IL-4 gene can be used as a biomarker to predict the risk of ESRD among Malaysians.

\section{MATERIAL AND METHODS}

Genomic DNA was extracted using the DNA Extraction Kit from BioBasic (Canada). Polymerase chain reaction (PCR) amplification was performed for VNTR polymorphism of the IL-4 gene in a $25-\mu \mathrm{L}$ reaction mixture containing $20 \mathrm{pM}$ forward and reverse primers, 0.4 $\mathrm{mM}$ each dNTP, $2 \mathrm{mM} \mathrm{MgCl}$, 1 X Taq buffer, 1 U NEB Taq DNA polymerase (New England Biolabs, Beverly, MA, USA) and the template DNA. The initial denaturation was set up for $10 \mathrm{~min}$ at $95^{\circ} \mathrm{C}$ followed by 32 cycles of denaturation for $30 \mathrm{~s}$ at $94^{\circ} \mathrm{C}$, annealing for $30 \mathrm{~s}$ at $60^{\circ} \mathrm{C}$, and extension for $30 \mathrm{~s}$ at $72^{\circ} \mathrm{C}$. PCR products were separated by $2 \%$ agarose gel electrophoresis and viewed under UV light. 


\section{RESULTS AND DISCUSSION}

To our knowledge, no previous studies have been carried out to determine the association of VNTR polymorphism in the IL-4 gene with ESRD subjects in Malaysian. Thus, this is the first study to report the relationship between VNTR polymorphism in the IL-4 gene and ESRD in a Malaysian population.

Approval of the study was obtained from the Ethics Committee of the Faculty of Medicine and Health Sciences, Universiti Putra Malaysia, under the Research Universiti Grant Schedule project. A total of 160 cases and 160 controls were recruited for this study. A questionnaire was prepared both in Malay and English languages to assess the socio-demographic characteristics of the study subjects. An informed consent form was obtained from those who fulfilled the selection criteria. There were significant differences with respect to gender, age, systolic blood pressure, diastolic blood pressure, serum creatinine level, and triglycerides, with $\mathrm{P}<0.05$, as compared to control subjects.

The VNTR polymorphism of the IL-4 gene was detected by the PCR method followed by agarose gel electrophoresis (Gyan et al., 2004). Figure 1 shows the VNTR polymorphism in intron 2 of the IL-1RN gene. Figure 1 also shows the VNTR polymorphism in intron 3 of IL-4 gene. Homozygous wild type (B1B1) had the highest frequency and percentage in case [74 (46.25\%)] and control subjects [86 (50.59\%)], followed by the heterozygous mutant type (B1B2) with $53(33.13 \%)$ and $68(40 \%)$, respectively, and the lowest frequency was seen in the homozygous mutation type (B2B2), that is, $33(20.63 \%)$ and $16(9.41 \%)$, respectively.

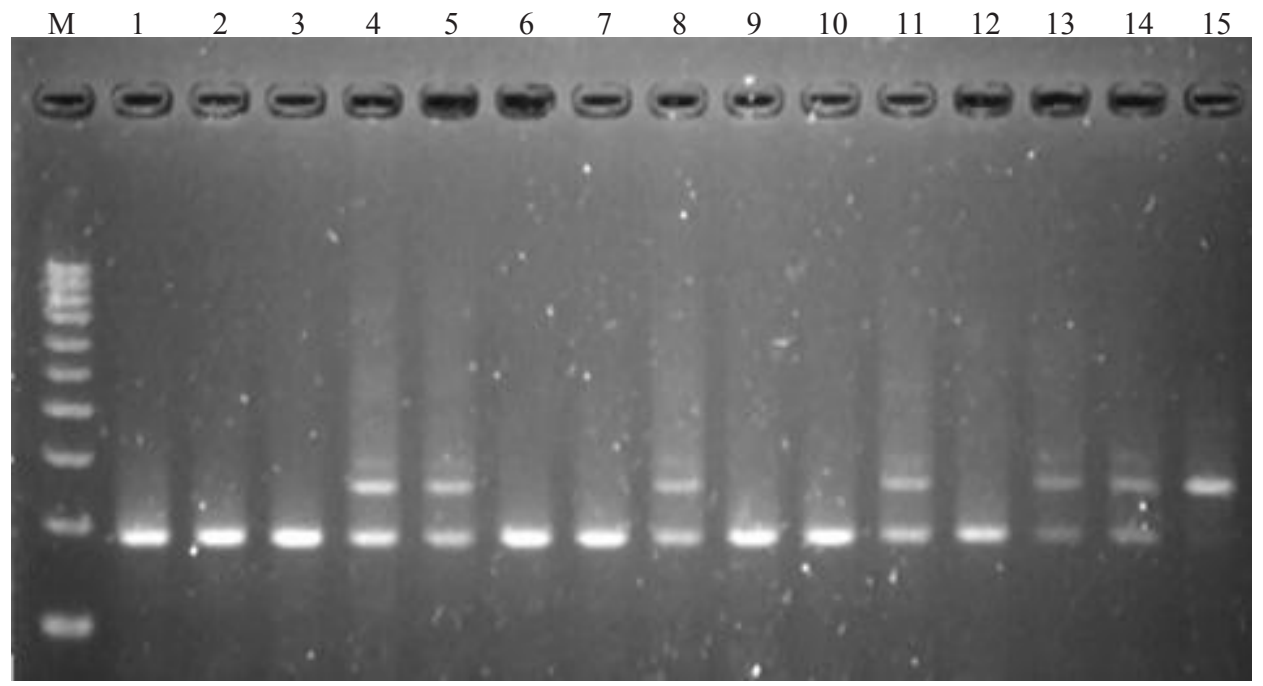

Figure 1. Detection of the VNTR gene polymorphism of the IL-4 gene on 2\% agarose gel electrophoresis. $\mathrm{M}=100$-bp marker. Lanes 1, 2, 3, 6, 7, 9, 10, and 12 show the B1 allele (183 bp). Lanes 4, 5, 8, 11, 13, and 14 show the B1B2 (183 and $253 \mathrm{bp}$ ) genotypes. Lane 15 shows the B2 allele (253 bp).

There were significant differences in genotypes and alleles of VNTR polymorphism of the IL-4 gene between ESRD patients and control subjects $(\mathrm{P}<0.05)$. To support our results, Table 1 shows the genotype and allele frequencies of the VNTR polymorphism of the IL-4 gene of ESRD patients among Asian populations. 


\begin{tabular}{|c|c|c|c|c|c|c|c|c|}
\hline \multirow[t]{2}{*}{ Population } & \multirow[t]{2}{*}{ No. } & \multirow[t]{2}{*}{ Age (years) } & \multicolumn{3}{|c|}{ Genotypes (\%) } & \multicolumn{2}{|c|}{ Alleles (\%) } & \multirow[t]{2}{*}{ Reference } \\
\hline & & & B1B1 & B1B2 & B2B2 & B1 & B2 & \\
\hline Malaysia & 160 & $25-86$ & 46.25 & 33.13 & 20.63 & 62.81 & $37.19^{*}$ & Present study \\
\hline North India & 193 & $17-64$ & 5.20 & 32.10 & 62.70 & 21.1 & 78.8 & Mittal and Manchanda, 2007 \\
\hline China & 91 & $13-74$ & 61.50 & 30.80 & 7.70 & 76.9 & 23.1 & Wu et al., 2003 \\
\hline Taiwan & 138 & $42-80$ & 86.00 & 13.00 & 1.0 & 93.9 & 7.0 & Tsai et al., 2005 \\
\hline
\end{tabular}

$* \mathrm{P}<0.05$, as compared to control subjects.

Our finding is consistent with findings in other Asian populations such as in an Indian population study (Mittal and Manchanda, 2007). Tsai et al. (2005) suggested that IL-4 gene intron 3 polymorphism was a potential genetic marker for the risk of bladder cancer. A significant association of IL-4 VNTR could influence the type of immune response and increase the development and progression of IgA nephropathy in a Japanese population (Nakashima et al., 2002; Masutani et al., 2003). However, our results were contradictory to findings for other populations (Wu et al., 2003). The discrepancies with previous studies may be due to ethnicity differences, heterogeneous population or sampling bias or possibly due to the environmental factors contributing to the negative associations (Persu, 2006). Furthermore, despite the considerable controversy regarding the existence and importance of ethnic differences in genetic effects for complex diseases, it seems evident that genetic markers for proposed gene-disease associations may vary in frequency across populations. Replication studies to confirm the association of IL-4 VNTR and other polymorphisms in the interleukin cluster genes with ESRD among Malaysians is strongly recommended. The current study has to be interpreted within the context of its limitations. IL-4 VNTR polymorphism was screened to determine whether it is a risk factor or not for the development of ESRD in Malaysian subjects. We did not address the mechanism or the functionality of the IL-4 VNTR polymorphism. The control subjects were not age- or gender-matched, and they were relatively young as compared to case subjects. Nonetheless, our findings strongly suggest that IL-4 VNTR polymorphism in the intron 3 region may be a risk factor for the development of ESRD among Malaysians.

\section{REFERENCES}

16th Report of the Malaysian Dialysis \& Transplant Registry (2008). The National Renal Registry. Malaysian Society of Nephrology, Kuala Lumpur.

Freedman BI, Yu H, Spray BJ, Rich SS, et al. (1997). Genetic linkage analysis of growth factor loci and end-stage renal disease in African Americans. Kidney Int. 51: 819-825. Doi: 10.1038/ki.1997.115.

Gyan BA, Goka B, Cvetkovic JT, Kurtzhals JL, et al. (2004). Allelic polymorphisms in the repeat and promoter regions of the interleukin-4 gene and malaria severity in Ghanaian children. Clin. Exp. Immunol. 138: 145-150. Doi: 10.1111/j.1365-2249.2004.02590.x.

Kirchheiner J, Grundemann D and Schomig E (2006). Contribution of allelic variations in transporters to the phenotype of drug response. J. Psychopharmacol. 20: 27-32. Doi: 10.1177/1359786806066043.

Konwar R and Bid HK (2008). Location of the 70bp VNTR polymorphic site is in third intron of IL-4 gene. Ind. J. Clin. Biochem. 23: 204-205. Doi: 10.1007/s12291-008-0046-y.

Masutani K, Miyake K, Nakashima H, Hirano T, et al. (2003). Impact of interferon-gamma and interleukin-4 gene polymorphisms on development and progression of IgA nephropathy in Japanese patients. Am. J. Kidney Dis. 41: 371-379. Doi: 10.1053/ajkd.2003.50046.

Mittal RD and Manchanda PK (2007). Association of interleukin (IL)-4 intron-3 and IL-6 -174 G/C gene polymorphism with susceptibility to end-stage renal disease. Immunogenetics 59: 159-165. Doi: 10.1007/s00251-006-0182-6.

Nakashima H, Miyake K, Inoue Y, Shimizu S, et al. (2002). Association between IL-4 genotype and IL-4 production in 
the Japanese population. Genes Immun. 3: 107-109. Doi: 10.1038/sj/gene/6363830.

Nordfors L, Lindholm B and Stenvinkel P (2005). End-stage renal disease-not an equal opportunity disease: the role of genetic polymorphisms. J. Intern. Med. 258: 1-12.

Persu A (2006). Candidate gene studies: accepting negative results. J. Hypertens. 24: 443-445. Doi: 10.1097/01. hjh.0000209978.98240.e5.

Tripathi G, Dharmani P, Khan F, Sharma RK, et al. (2006). High prevalence of ACE DD genotype among north Indian end stage renal disease patients. BMC Nephrol. 7: 15.

Tripathi G, Sharma RK, Baburaj Pv, Sankhwar NS, et al. (2008). Genetic risk factor for renal failure among North Indian ESRD patients. Clin. Biochem. 41: 525-531.

Tsai FJ, Chang CH, Chen CC, Hsia TC, et al. (2005). Interleukin-4 gene intron-3 polymorphism is associated with transitional cell carcinoma of the urinary bladder. BJU Int. 95: 432-435.

Wetmore JB, Hung AM, Lovett DH, Sen S, et al. (2005). Interleukin-1 gene cluster polymorphisms predict risk of ESRD. Kidney Int. 68: 278-284. Doi: 10.1111/j.1523-1755.2005.00403.x.

Wu MC, Huang CM, Tsai JJ, Chen HY, et al. (2003). Polymorphisms of the interleukin-4 gene in chinese patients with systemic lupus erythematosus in Taiwan. Lupus 12: 21-25. Doi: 10.1191/09612033031u249oa.

Yao Q, Lindholm B and Stenvinkel P (2004). Inflammation as a cause of malnutrition, atherosclerotic cardiovascular disease, and poor outcome in hemodialysis patients. Hemodial. Int. 8: 118-129. 